\title{
Management of Root Knot Nematode (Meloidogyne incognita) in Tomato (cv. Pusa ruby) using Different Oil Cakes
}

\author{
Sasmita Sahu, Mukesh Kumar Patra* and Byomakesh Dash \\ Department of Nematology, College of Agriculture, OUAT, \\ Bhubaneswar-751003, Odisha, India \\ *Corresponding author
}

\begin{tabular}{|c|}
\hline Keywords \\
\hline $\begin{array}{l}\text { Different oil cakes, } \\
\text { Carbofuran, Chlorophyll, } \\
\text { Meloidogyne incognita, } \\
\text { Solanum lycopersicum }\end{array}$ \\
\hline Article Info \\
\hline $\begin{array}{l}\text { Accepted: } \\
20 \text { February } 2018 \\
\text { Available Online: } \\
10 \text { March } 2018\end{array}$ \\
\hline
\end{tabular}

\section{A B S T R A C T}

A replicated pot culture experiment was conducted to study the comparative efficacy of different oil cakes on management of root knot nematode (Meloidogyne incognita) infecting tomato. The results revealed that barring the untreated check, all other treatments significantly increased the plant growth parameters, total chlorophyll content and reduced root knot nematode population as well as number of galls. Among various treatments, $\mathrm{T}_{8}$ where neem cake @ $100 \mathrm{~g} / \mathrm{m}^{2}$ and $\mathrm{T}_{7}$ where mahua cake $100 \mathrm{~g} / \mathrm{m}^{2}$ were applied in pot soil, resulted plant growth parameters, total chlorophyll content and population growth of root knot nematode were found statistically at par. Both the aforesaid $T_{8}$ and $T_{7}$ treatments performing better than others contributed significantly as percentage of increase in plant height by $85.91 \%$ and $73.84 \%$, fresh shoot weight by $60.66 \%$ and $55.85 \%$, root length by $89.50 \%$ and $78.43 \%$, fresh root weight by $87.04 \%$ and $78.98 \%$, total chlorophyll content by $83.09 \%$ and $72.88 \%$ with corresponding decrease in order of number of root galls by $78.91 \%$ and $68.06 \%$ over untreated inoculated check $\left(\mathrm{T}_{10}\right)$. Though $\mathrm{T}_{7}$ and $\mathrm{T}_{8}$ exhibited better results as compared to other treatments and over check $\left(\mathrm{T}_{10}\right)$, yet in view of easy availability and low management option, application of neem oil cake @ $100 \mathrm{~g} / \mathrm{m}^{2}$ in $\mathrm{T}_{8}$ is considered the most promising management option against root knot nematode (Meloidogyne incognita) infecting tomato.

\section{Introduction}

Tomato (Solanum lycopersicum L.) belonging to the family Solanaceae is one of the most important and nutritive vegetable crop grown all over the world. India is the second largest tomato producer and occupies second position amongst the vegetable crops in terms of production. Among the major biotic factors that affect the tomato production, root knot nematode (Meloidogyne incognita) is the most serious pest causing considerably low yield in all parts of India. Root knot nematode causes an annual loss approximately $27.24 \%$ in tomato in India (Jain et al., 2007). Among different species of Meloidogyne, M. incognita is the most widely distributed species on tomato in Odisha. Management of nematode problems by applying chemical pesticides causes serious concern about environment and human health and also has residual toxicity which persists for more than 45 days affecting beneficial soil microbes. Therefore, incorporation of cultural and use of biocontrol 
agents including organic amendments and botanicals have been regarded to be effective against nematode infestations. Organic amendments like oil cakes can provide safe and pollution free control of plant parasitic nematodes. Oil cakes change the physical and chemical properties of the soil which makes the soil atmosphere unfavorable for nematode activity and improves soil condition for greater root growth there by increasing the utilization of soil nutrients.

Therefore, an attempt was made to evaluate the efficacy of certain organic amendments and carbofuran $3 \mathrm{G}$ both individually under field condition to manage root-knot nematode problem infecting tomato.

\section{Materials and Methods}

Seeds of tomato, $c v$. Pusa ruby were obtained from AICRP on Nematodes in cropping system, OUAT, Bhubaneswar. The seeds were surface sterilized in $2.5 \%$ Sodium hypochlorite solution for two minutes followed by rinsing seeds thrice with distilled water followed by air drying in shade. The seeds were sown in $30 \mathrm{~cm}$ diameter earthen pots containing steam sterilized soil mixture. Three such pots were maintained in the net house. Light watering was done as and when necessary.

Each of the oil cakes@100g/m² were mixed thoroughly to the autoclaved soil $(1 \mathrm{~kg})$ filled in separate surface sterilized $15 \mathrm{~cm}$ dia. earthen pots followed by light watering. All these pots were maintained as such in the net house for a period of 7 days for proper decomposition of oilcakes. A chemical checks with carbofuran @ $0.3 \mathrm{~g}$ ai $/ \mathrm{m}^{2}$ was kept for comparison and mixed with pot soil. An inoculated check was also maintained. Hence, there were all together 10 treatments with 3 replications arranged in Completely Randomized Design (CRD). The treatments were
$\mathrm{T}_{1}$ - Soil application of Karanja oil cake @ $100 \mathrm{~g} / \mathrm{m}^{2}$

$\mathrm{T}_{2}$ - Soil application of Mustard oil cake @ $100 \mathrm{~g} / \mathrm{m}^{2}$

$\mathrm{T}_{3}$ - Soil application of Jatropha oil cake @ $100 \mathrm{~g} / \mathrm{m}^{2}$

$\mathrm{T}_{4}$ - Soil application of Groundnut oil cake @ $100 \mathrm{~g} / \mathrm{m}^{2}$

$\mathrm{T}_{5}$ - Soil application of Polango oil cake @ $100 \mathrm{~g} / \mathrm{m}^{2}$

$\mathrm{T}_{6}$ - Soil application of Kusum oil cake @ $100 \mathrm{~g} / \mathrm{m}^{2}$

$\mathrm{T}_{7}$ - Soil application of Mahua oil cake @ $100 \mathrm{~g} / \mathrm{m}^{2}$

$\mathrm{T}_{8}$ - Soil application of Neem oil cake@ $100 \mathrm{~g} / \mathrm{m}^{2}$

$\mathrm{T}_{9}$ - Soil application of Carbofuran @ 0.3g a.i. $/ \mathrm{m}^{2}$

$\mathrm{T}_{10}$ - Untreated inoculated check

Tomato seedlings raised in sterilized soil were transplanted in the pots ( 1 in each pot). Fifteen days old seedlings were used for transplanting in pot culture experiments. At one week after transplanting thousand freshly hatched second stage juvenile of $M$. incognita were inoculated to each pot followed by a light watering. This experiment was terminated after 45 days of inoculation during which care of each seedlings and other intercultural operations were attended regularly.

After 45 days of inoculations, the data of plant height and root length, fresh shoot and root weight, number of galls per plant, and also total chlorophyll content in leaves were recorded. Various observations recorded from 
different treatments and tabular data were subjected to statistical analysis for each parameter for comparison of different treatments following Fisher's method of analysis of variance at $5 \%$ level.

\section{Results and Discussion}

The effect of different oil cakes like karanja, mustard, jatropha, groundnut, polango, kusum, mahua and neem were estimated on the basis of the differential changes in plant growth parameters (Plant height, fresh and dry shoot weight) and nematode infection parameter as number of galls and also total chlorophyll content in leaves.

The data (Table 1) indicated that there was progressive increase in plant growth parameters in respect of plant height, fresh shoot and root weight in all treatments over untreated check. Application of neem cake @ $100 \mathrm{~g} / \mathrm{m}^{2}$ resulted maximum increase of plant growth parameters in comparison to untreated check where as it was minimum with the incorporation of mustard oil cake. Neem cake caused $85.91 \%, 60.66 \%, 89.50 \%$ and $87.04 \%$ significant increase in plant height, fresh shoot weight, root length and fresh root weight respectively. This was followed by Mahua cake with $73.84 \%, 55.85 \%, 78.43 \%$ and $78.98 \%$ increase over control in the above parameters. In the contrary, least significant increase was observed in these parameters with incorporation of mustard oil cake. This result corroborates with the findings of Rathar and Siddiqui (2007) and Kalaiarasan et al., (2007) that proved the effectiveness of oilcakes improving plant growth and reducing nematode population in tomato. Increased microbial activity in amended soil is to bring about increased conversion of nitrogen to nitrate form, resulted ultimately in increased metabolic activity of plants and plant growth (Prasad and Tomar, 2007). This supports the findings in $\mathrm{T}_{8}$ (neem oil cake @100g/ $\mathrm{m}^{2}$ ) where there is better growth of tomato plant. Singh et al., (2009) and Sreenivasan (2010) applied neem oilcakes and found significant increase in the plant growth and decrease in root knot nematode population in green gram and medicinal coleus respectively. Similar observation was also reported by Srivastava, (2002) in papaya.

The results were also in conformity with the work of Bhattacharya and Goswami, (1989) who observed that significant increase in plant growth in crops treated with neem cake infected by $M$. incognita. Neem cake at 80 $\mathrm{q} / \mathrm{ha}$ was found to be more effective than carbofuran at $2 \mathrm{~kg}$ a.i. /ha in reducing rootknot nematode population and enhanced plant growth on tomato (Jain and Gupta, 1997).

So far as population growth of $M$. incognita is concerned, data (Table 2) indicated that there was decline in number of galls in all treatment over untreated check. Singh et al., (2009) and Sreenivasan (2010) also observed similar results with use of oilcakes. Highest reduction in galls was noticed in treatment having neem oil cake (248.33) followed by mahua oil cake (376) than untreated check (1177.33). Highest reduction in percentage of galls was noticed in $\mathrm{T}_{8}(78.91 \%)$ followed by $\mathrm{T}_{7}(68.06 \%), \mathrm{T}_{6}$ (61.81\%), $\mathrm{T}_{9}(52.12 \%), \mathrm{T}_{5}(41.96 \%), \mathrm{T}_{4}$ (38.28\%), $\mathrm{T}_{1}(29.16 \%), \mathrm{T}_{2}(16.65 \%)$ and $\mathrm{T}_{3}$ $(11.13 \%)$ over check in descending order. This finding was agreement with the findings of Cavoski et al., (2011) and Mehlhom et al., (2011). They reported that neem is one of the most important botanical pesticides which possess fungicidal, nematicidal, bactericidal molluscidial, diuretic and antiarthritic properties. Singh et al., (2012) reported in chickpea that ammonia, hydrogen sulphide and phenolic compounds were released following the decomposition of organic additives in the soil. These compounds were found detrimental to the population build-up of nematodes in vitro. 
Table.1 Influence of Meloidogyne incognita in different oilcakes on plant growth parameters of tomato cv. Pusa ruby

\begin{tabular}{|c|c|c|c|c|c|c|c|c|}
\hline Treatments & $\begin{array}{c}\text { Shoot } \\
\text { Length }(\mathrm{cm})\end{array}$ & $\begin{array}{l}\text { Percentage of } \\
\text { increase }\end{array}$ & $\begin{array}{c}\text { Fresh } \\
\text { Shoot } \\
\text { Weight (g) }\end{array}$ & $\begin{array}{c}\text { Percentage } \\
\text { of } \\
\text { increase }\end{array}$ & $\begin{array}{c}\text { Root } \\
\text { length } \\
(\mathrm{cm})\end{array}$ & $\begin{array}{c}\text { Percentage } \\
\text { of } \\
\text { increase }\end{array}$ & $\begin{array}{l}\text { Fresh } \\
\text { Root } \\
\text { Weight (g) }\end{array}$ & $\begin{array}{c}\text { Percentage } \\
\text { of } \\
\text { increase }\end{array}$ \\
\hline $\mathrm{T}_{1}$ (Karanja oilcake @ 100g/m²) & 46.74 & 26.43 & 48.67 & 18.71 & 18.13 & 14.03 & 12.77 & 18.24 \\
\hline $\mathrm{T}_{2}$ (Mustard oilcake @ 100g/m²) & 44.7 & 20.91 & 46.6 & 13.66 & 17.70 & 11.32 & 12.07 & 11.76 \\
\hline $\mathrm{T}_{3}$ (Jatropha oilcake @ 100g/m²) & 41.23 & 11.52 & 45.17 & 10.17 & 17.50 & 10.06 & 11.9 & 10.19 \\
\hline $\mathrm{T}_{4}$ (Groundnut oilcake @ 100g/m²) & 50.63 & 36.95 & 51.97 & 26.76 & 20.53 & 29.12 & 14.1 & 30.56 \\
\hline $\mathrm{T}_{5}$ (Polango oilcake @ 100g/m²) & 52.7 & 42.55 & 52.97 & 29.20 & 21.03 & 32.26 & 15 & 38.89 \\
\hline $\mathrm{T}_{6}$ (Kusum oilake @ 100g/m²) & 62.33 & 68.60 & 58.5 & 42.68 & 26.37 & 65.85 & 17.93 & 66.02 \\
\hline $\mathrm{T}_{7}$ (Mahua oilcake @ 100g/m²) & 64.27 & 73.84 & 63.9 & 55.85 & 28.37 & 78.43 & 19.33 & 78.98 \\
\hline $\mathrm{T}_{8}$ (Neem oilcake@100g/m²) & 68.73 & 85.91 & 65.87 & 60.66 & 30.13 & 89.50 & 20.2 & 87.04 \\
\hline $\mathrm{T}_{9}$ (Carbofuran@1kg a.i/ha) & 56.23 & 52.10 & 55.83 & 36.17 & 23.83 & 49.87 & 16.63 & 53.98 \\
\hline $\mathrm{T}_{10}$ (Untreated check) & 36.97 & - & 41 & - & 15.90 & - & 10.8 & - \\
\hline S.E. (m) & 2.12 & - & 1.72 & - & 0.75 & - & 0.43 & - \\
\hline L.S.D (0.05) & 6.27 & - & 5.08 & - & 2.21 & - & 1.27 & - \\
\hline
\end{tabular}

Table.2 Effects of oil cake on number of galls in roots and chlorophyll content of leaves in tomato cv. Pusa ruby infected by Meloidogyne incognita

(Average of 3 replications)

\begin{tabular}{|c|c|c|c|c|}
\hline Treatments & No. of Galls & $\begin{array}{c}\text { Percentage of } \\
\text { decrease }\end{array}$ & Total Chlorophyll content (mg/g) & Percentage of increase \\
\hline $\mathrm{T}_{1}$ (Karanja oilcake @ 100g/m²) & $834(2.92)^{*}$ & 29.16 & 1.55 & 42.20 \\
\hline $\mathrm{T}_{2}$ (Mustard oilcake @ 100g/m²) & $981.33(2.99)$ & 16.65 & 1.54 & 41.28 \\
\hline$T_{3}$ (Jatropha oilcake @ 100g/m²) & $1046.33(3.02)$ & 11.13 & 1.47 & 34.86 \\
\hline $\mathrm{T}_{4}$ (Groundnut oilcake @ 100g/m²) & $726.67(2.86)$ & 38.28 & 1.66 & 52.29 \\
\hline $\mathrm{T}_{5}$ (Polango oilcake @ 100g/m²) & $683.33(2.83)$ & 41.96 & 1.73 & 58.72 \\
\hline$T_{6}$ (Kusumoilake @ 100g/m²) & $449.67(2.65)$ & 61.81 & 1.83 & 67.89 \\
\hline $\mathrm{T}_{7}$ (Mahua oilcake @ 100g/m²) & $376(2.57)$ & 68.06 & 1.92 & 76.15 \\
\hline $\mathrm{T}_{8}$ (Neem oilcake @ 100g/m²) & $248.33(2.37)$ & 78.91 & 1.99 & 82.57 \\
\hline T9 (Carbofuran@1kg a.i/ha) & $563.67(2.75)$ & 52.12 & 1.82 & 66.97 \\
\hline $\mathrm{T}_{10}$ (Untreated check) & $1177.33(3.07)$ & - & 1.09 & - \\
\hline S.E. $(\mathbf{m})$ & 0.048 & - & 0.03 & - \\
\hline L.S.D (0.05) & 0.14 & - & 0.08 & - \\
\hline
\end{tabular}

*Figures in parentheses indicate log transformed values 
With regards to data (Table 2), it was noticed that application of oilcakes significantly increased the chlorophyll content in leaves of tomato plant. Neem cake treatment effectively increased the chlorophyll content by $73.1 \%$ followed by mahua cake $(64.1 \%)$ as compared to the untreated one. Similarly, mustard oil cake was least effective in increasing the chlorophyll content of the leaves as compared to all other treatments. Siddiqui and Akhtar (2008) observed that the increase in chlorophyll contents in leaves in the presence of decomposed organic wastes is due to increase in $\mathrm{N}$ uptake by the addition of organic compounds resulted in increased photosynthetic efficiency, translocation of nutrients, and other metabolites toward formation of fruits. Similarly, Oka et al., (2007) reported that nitrogen content in form of ammonium present in organic amendments which is more harmful to nematodes.

To conclude with the present investigation, it was evident that the application of neem oil cake@100g/m² and mahua oil cake @ $100 \mathrm{~g} / \mathrm{m}^{2}$ provided better for management but in view of easy availability and low management option, application of neem oil cake@ $100 \mathrm{~g} / \mathrm{m}^{2}$ in $\mathrm{T}_{8}$ is considered the most promising management option against root knot nematode (Meloidogyne incognita) infecting tomato. However, it is worthwhile to study the efficacy of the treatment in the field condition for more meaningful result in managing root-knot nematode.

\section{References}

Bhattacharya, D., and Goswami, B.K. 1987a. A study on the comparative efficacy of neem and ground nut oil cakes against root-knot nematode, Melodogyne incognita as influenced by microorganisms on sterilized and unsterilized soil, Indian Journal of Nematology, 17: 81-83.
Cavoski, I., Caboni, P., and Miano, T. 2011. Natural pesticides and future perspectives. In: Margarita Stoytcheva ed. Pesticides in the modern world pesticides use and management. InTech open science. Pp 169-190.

Jain, R.K., and Gupta, D.C. 1997. Efficacy of neem (Azadirachta indica) cake as nursery bed treatment in the management of root knot nematode (Meloidogyne javanica) infecting tomato, Indian Journal of Nematology, 27(2): 249-252.

Jain, R.K., Mathur, K.N. and Singh, R.V. 2007. Estimation of losses due to plant parasitic nematodes on different crops in India, Indian Journal of Nematology, 37(2):219-221.

Kalaiarasan, P., Senthamarai, M., Ramesh, D. and Sudheer, M.J. 2007. Jatropha: An efficient organic amendment for the management of root-knot nematode, Meloidogyne incognita in tomato, Indian Journal of Nematology, 37(2): 115-118.

Mehlhom, H., Al-Rasheid, K.A.S., and Abdel-Ghaffar F. 2011. The neem tree story: Extracts that really work. In: H. Mehlhom (Ed.) Nature helps, parasitology research (Monographs 1), Springer-Verlag, Berlin. Pp 77-108.

Oka, Y., Tkachi, N., Shuker, S., and Yerumiyahu, U. 2007. Enhanced nematicidal activity of organic and inorganic ammonia releasing amendments by Azadirachta indica extracts, Journal of Nematology, 39(1): 9-16.

Prasad, D., and Tomar, S.S. 2007. Toxicity of plant extracts against root knot and reniform nematodes, Annals of Plant Protection Science, 15: 535-537.

Rather, M.A. and Siddiqui, M.A. 2007. Neem for the control of root-knot nematode infecting tomato, Indian Journal of Nematology, 37(1): 81-110. 
Siddiqui, Z.A., and Akhtar, M.S. 2008. Arbuscular mycorrhizal fungi as potential biprotectants against plant pathogens. In Z. A. Siddiqui, M. S. Akhtar, \& K. Futai (Eds.), Mycorrhizae: Sustainable agriculture and forestry. Pp. 61-97.

Singh, K.S., Azam, M.F., Gurjar, M.S., and Shahid, A. 2012. Effect of plant extracts against Meloidogyne incognita on chick pea, Annals of Plant Protection Science, 20(2): 449-451.

Singh, S., Kumar, S., and Verma, R.A. 2009. Management of Meloidogyne incognita through organic amendments on green gram, Annals of Plant Protection Science, 17(1): 185-187.

Sreenivasan, N. 2010. Management of rootknot nematode, Meloidogyne incognita with organic amendments in medicinal coleus, Annals of Plant Protection Science, 18(2): 472-476.

Srivastava, S.S. 2002. Efficacy of organic amendments in the management of root knot nematode (Meloidogyne incognita) infecting papaya, Indian Journal of Nematology, 32(2): 183-185.

\section{How to cite this article:}

Sasmita Sahu, Mukesh Kumar Patra and Byomakesh Dash. 2018. Management of Root Knot Nematode (Meloidogyne incognita) in Tomato (cv. Pusa ruby) using Different Oil Cakes. Int.J.Curr.Microbiol.App.Sci. 7(03): 2527-2532. doi: https://doi.org/10.20546/ijcmas.2018.703.292 